I N S T I T U T O

DE

M E D I C I N A

T R O P I C A L

DE

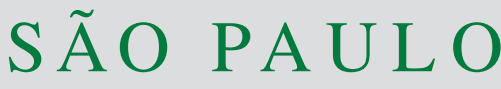

JOURNAL OF THE SÃO PAULO INSTITUTE OF TROPICAL MEDICINE

${ }^{1}$ Universidade Federal do Estado do Rio de Janeiro, Hospital Universitário Gaffrée e Guinle, Centro de Ciências Biológicas e da Saúde, Rio de Janeiro, Rio de Janeiro, Brazil

*The first two authors contributed equally to the study

Correspondence to: Walter de Araujo Eyer-Silva

Universidade Federal do Estado do Rio de Janeiro (UNIRIO), Hospital Universitário

Gaffrée e Guinle, Departamento de

Medicina Geral, Centro de Ciências

Biológicas e da Saúde, $10^{\text {a }}$ enfermaria,

Rua Mariz e Barros, 775, CEP 20270-004,

Tijuca, Rio de Janeiro, RJ, Brazil.

Tel: +55 21999537051

E-mail: walter.eyer@ig.com.br

Received: 4 April 2018

Accepted: 16 July 2018
http://dx.doi.org/10.1590/S1678-9946201860040

\section{Secondary syphilis presenting as a corymbiform syphilide: case report and review}

Walter de Araujo Eyer-Silva*1, Viviane Primo Basílio de Souza*1, Guilherme Almeida Rosa da Silva', Fernando Vieira Brasil', Alessandra dos Santos Portela1, Ricardo de Souza Carvalho', Rogerio Neves-Motta1, Carlos José Martins $^{1}$

\section{ABSTRACT}

It is essential that healthcare providers are familiar with the full spectrum of clinical presentations of syphilis. A rare manifestation of secondary syphilis is the corymbiform (or corymbose) arrangement, in which a central greater papule is surrounded by smaller satellite lesions. Very few reports of corymbiform syphilis are available in current biomedical databases. We present the case of a 28 year-old HIV-infected male patient on regular, successful antiretroviral therapy who developed an asymptomatic corymbiform maculopapular lesion in the medial aspect of the right thigh. There were also a few brownish macular lesions on the left sole. New serological tests for syphilis (which had been negative in the past) were reactive. The coymbiform lesion slowly regressed and the non-treponemal test reverted to negative after benzathine penicillin $G$ treatment. A review of the literature is provided. This is the first report of corymbiform syphilis in an HIV-infected patient.

KEYWORDS: Corymbiform. Corymbose. HIV infection. Syphilis.

\section{INTRODUCTION}

Acquired syphilis is a sexually transmitted infection caused by the spirochete Treponema pallidum, subspecies pallidum. It is a major public health problem worldwide. The disease has been coined "the great imitator" due to its great variability of presentation and mimicry of other conditions ${ }^{1}$. Physicians unaware of its protean manifestations may easily overlook atypical presentations. Patients infected with the human immunodeficiency virus (HIV) tend to have a greater frequency of aggressive and unusual clinical phenotypes of syphilis ${ }^{2}$. We have recently had the opportunity to care for some patients with unusual clinical presentations of syphilis during the course of HIV infection ${ }^{3-6}$. We now report the case of a male patient in whom secondary syphilis presented with an exceedingly rare type of lesion: a corymbiform (or corymbose) syphilide.

\section{CASE REPORT}

A 28 year-old HIV-infected male patient who was on regular antiretroviral therapy for more than two years presented with an asymptomatic cutaneous eruption first noted three months earlier (Figure 1A). Physical examination revealed a brownish maculopapular lesion in the medial aspect of the right thigh. It consisted of a major lesion that was slightly raised and darker in the center, giving a somewhat aspect 
of an areola or a target. The major lesion was surrounded by a ring of much smaller peripheral circumoval macules (Figure 1). The overall aspect shared close resemblance with the previously described corymbiform syphilide ${ }^{7}$. There were also a few brownish macular lesions on the left sole, but the palms and the right sole were spared (Figure 1B). No evidence of lymphadenopathy or mucosal lesions was recorded.

There was no serological evidence of hepatitis B or hepatitis $C$ infection. The CD4 cell count was 361 cells $/ \mathrm{mm}^{3}$ and HIV viral load was below detection limits. Previous routine tests had been negative for syphilis, but new tests showed a Venereal Disease Research Laboratory (VDRL) titer of $1 / 8$ and a reactive fluorescent treponemal antibody absorption test. Diagnosis of secondary syphilis presenting as a corymbiform syphilide was made. The patient could not recall having had any previous cutaneous rash, genital or extragenital chancre, but was sexually active and engaged in unprotected sex with men. Three consecutive weekly administrations of 2.4 million units of intramuscular benzathine penicillin $\mathrm{G}$ were prescribed. The corymbose lesion slowly started to fade, but the VDRL titer remained $1 / 8$ four months after the beginning of treatment. The plantar lesions completely disappeared.

In the case review, we realized that only 1.2 million units (instead of a cumulative dose of 7.2 million units) of intramuscular benzathine penicillin $\mathrm{G}$ had been actually administered. Therefore, three additional consecutive weekly administrations of 2.4 million units of intramuscular benzathine penicillin $\mathrm{G}$ were prescribed. Six months later, the corymbiform lesion could no longer be recognized. No Jarisch-Herxheimer reaction occurred and the VDRL test reverted to negative. Cerebrospinal fluid examination was normal, with a negative VDRL test. A cutaneous biopsy, which we had planned and scheduled prior to treatment, was not performed due to internal problems at the hospital. Molecular tests were not available at that time. The patient was advised to bring his sexual partners to medical attention.

\section{DISCUSSION}

Atypical cutaneous manifestations of the secondary syphilitic rash may be more common than generally assumed and include (but are not limited to) annular, nodular, pustular, psoriasiform, circinate, bullous, rupioid, framboesiform, nodular-ulcerative, ulceronecrotic, granulomatous, vesicular, follicular, pigmentary (leukoderma syphiliticum and pigmentary syphilide), and corymbose lesions ${ }^{7,8}$. Very few case reports of syphilitic lesions of the corymbose type are available in current biomedical databases ${ }^{2,9-13}$.

A corymbose (or corymbiform) arrangement (from the Greek kórymbos, cluster of fruits or flowers) comprises a central greater papule surrounded by smaller satellite lesions. Adamson ${ }^{9}$ reported in the early twentieth century that corymbose syphilis was a well-known though somewhat rare type of syphilide. After many years of syphilology practice, Fournier ${ }^{14}$ considered syphilide papuleuse en corymbe a rare and bizarre presentation of secondary syphilis that was "very significant due to its singularity". In his Traité de la Syphilis, he described the lesion as a grouped eruption, but an eruption "grouped in a very special way": a central common papule (major papule) that was "larger in dimension and of greater intensity of color", surrounded by minor papules that gave an overall aspect of an "astronomical system"14. Moreover, Fournier considered corymbose lesions a late expression of secondary syphilis, a position shared by some authors currently ${ }^{2}$. According to Greaves ${ }^{15}$, the most frequent site of election of this type of

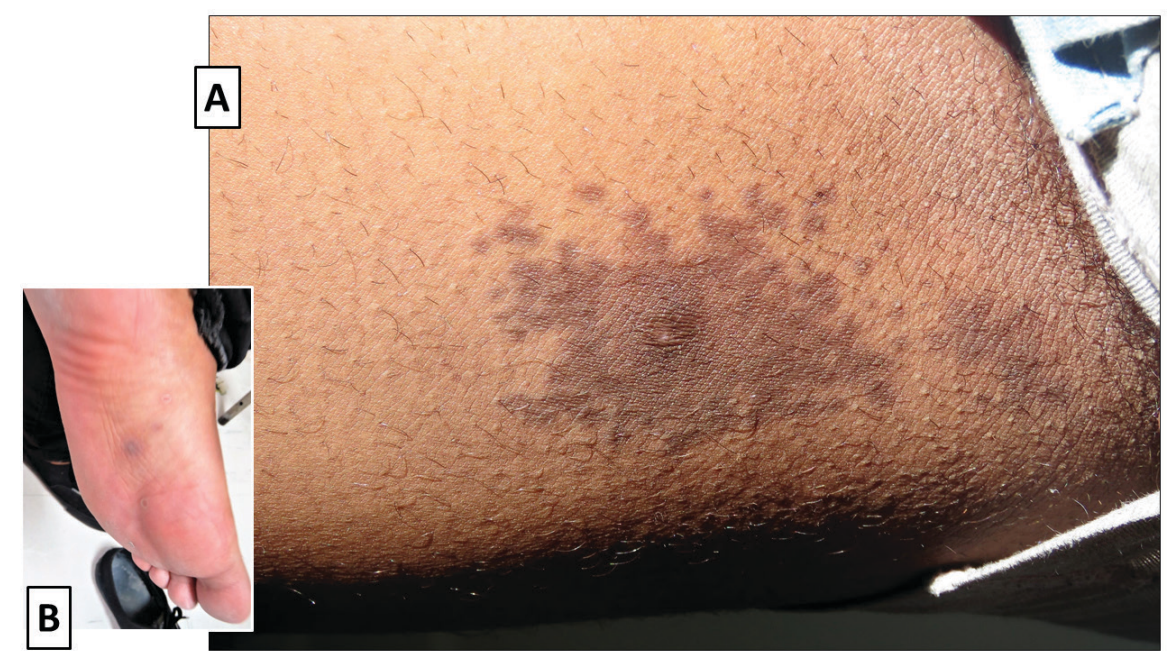

Figure 1 - Clinical aspect of the 28 year-old HIV-infected male patient.: A) a corymbose syphilide in the medial aspect of the right thigh; B) brownish macular lesions on the left sole 
syphilide was the back, especially along a transverse line drawn through the center of both scapula. However, we could not find modern case reports with such a topography. Writing in the 1930s, John H. Stokes ${ }^{16}$ proposed in his Modern Clinical Syphilology that many corymbose lesions are "recurrences and relapses and are distinct evidence of increased severity of cutaneous reaction and a tendency toward malignant syphilis". This classic text offers some historic images of corymbiform syphilides that share close resemblance to our patient's rash (Figure 2). Some authors have also suggested that corymbose syphilis may be a sign of reinfection ${ }^{10,13}$. Finally, Baughn and Musher ${ }^{7}$ stated that no other dermatologic disease causes this type of lesion.

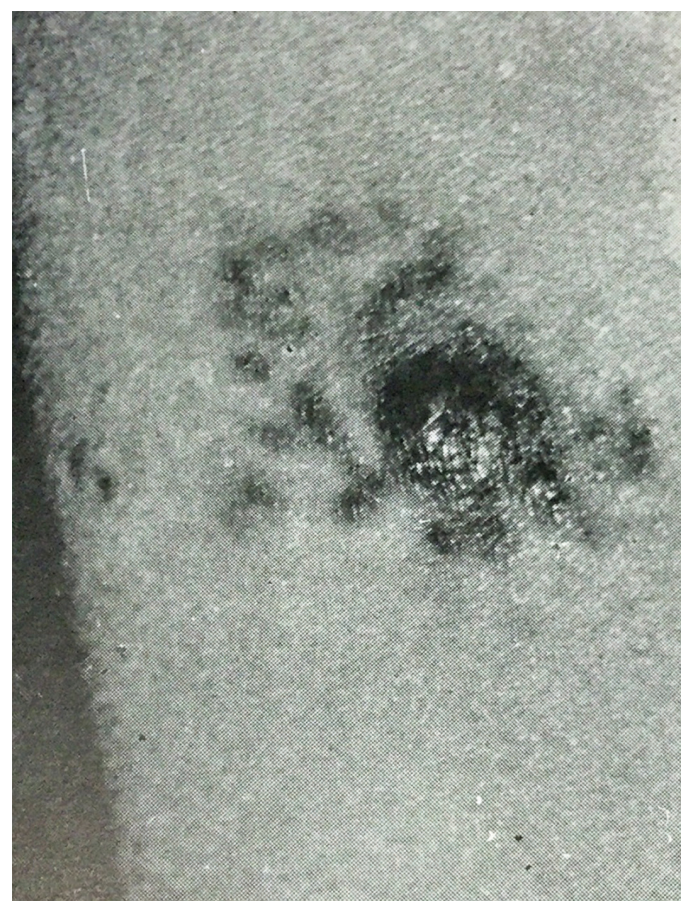

Figure 2 - Clinical aspect of a corymbiform syphilid, as reported by John H. Stokes in his classic 1934 textbook Modern clinical syphilology (p. 625) ${ }^{16}$. Gender and sex of the patient were not informed. The lesion shares close resemblance to our patient's rash. Reproduced with permission from the editors

Our patient's corymbiform lesion readily started to fade after initiation of penicillin treatment. Nontreponemal tests, however, only reverted after three consecutive weekly administrations of 2.4 million units of intramuscular benzathine penicillin $\mathrm{G}$ were administered. The few available reports of corymbiform syphilis showed full clinical recovery after appropriate treatment ${ }^{2,10,13}$. Our patient presented with few dermatologic lesions. Corymbose syphilis may present as single ${ }^{2,10}$ or several $^{12,13}$ corymbiform arrangements. Fournier ${ }^{14}$ suggested that fewer lesions are an indication of late presentations of secondary syphilis. Our patient also had a relatively low VDRL titer for secondary syphilis standards. It was not clear if the clinical picture could be due to an unusual late form of secondary syphilis or a sign of reinfection.

Unfortunately, a cutaneous biopsy was not performed. Histopathological examination, as well as studies of molecular amplification of $T$. pallidum sequences, could add interesting data, especially in cases in which the diagnosis of syphilis is not enough clear from the clinical and serological findings. However, we believe that there is no doubt on the diagnosis of secondary syphilis with a corymbose syphilid in the present case. Our patient presented with the corymbiform rash associated with syphilitic macules on the left sole and reactive treponemal and non-treponemal tests, which were previously negative. The skin lesions remitted and the non-treponemal test reverted to negative after treatment.

In summary, we present an exceedingly unusual case of secondary syphilis presenting with a corymbiform syphilide. Any patient presenting with unexplained cutaneous rash should be properly investigated for syphilis. Failure to recognize and appropriately treat syphilitic lesions may have ominous consequences, since the lesions will undergo spontaneous remission, entering into a latent stage, and lifethreatening complications may eventually ensue. Therefore, a skilled clinician shall constantly exercise a heightened awareness of the multifaceted presentations of syphilis.

\section{CONFLICT OF INTERESTS}

The authors declare there is no conflict of interest.

\section{INFORMED CONSENT}

Informed consent of the patient was obtained for publication of the case.

\section{FINANCIAL SUPPORT}

\section{None.}

\section{AUTHORS' CONTRIBUTIONS}

WAES, VPB, and CJM proposed the publication of the case. WAES and VPB drafted the manuscript. WAES, VPB, GARS, FVB, ASP, DJHPS, RSC, RNM, and CJM took part in the clinical management of the patient. All authors revised the literature and provided important contributions to conception, design, acquisition of data, analysis, interpretation, and intellectual contributions to the final version. 


\section{REFERENCES}

1. Dourmishev LA, Dourmishev AL. Syphilis: uncommon presentations in adults. Clin Dermatol. 2005;23:555-64.

2. Shimizu S, Yasui C, Tajima Y, Tsuchiya K. Unusual cutaneous features of syphilis in patients positive for human immunodeficiency virus. Clin Exp Dermatol. 2010;35:169-72.

3. dos Santos TR, de Castro IJ, Dahia MM, de Azevedo MC, da Silva GA, Motta RN, et al. Malignant syphilis in an AIDS patient. Infection. 2015;43:231-6.

4. Eyer-Silva WA, Silva GA, Ferry FR. Olecranon bursitis, Beau's lines, Biett's collarettes, and crown of Venus. Am J Trop Med Hyg. 2017;96:261-2.

5. Eyer-Silva WA, Martins CJ, Silva GA, Acakpovi G, Pinto JF. Secondary syphilis presenting as leucoderma syphiliticum: case report and review. Rev Inst Med Trop Sao Paulo. 2017;59:e74.

6. Eyer-Silva WA, Freire MA, Horta-Araujo CA, Silva GA, Pinto JF, Ferry FR. Secondary syphilis presenting as glossodynia, plaques en prairie fauchée, and a split papule at the oral commissure: case report and review. Case Rep Med. 2017;2017:1980798.

7. Baughn RE, Musher DM. Secondary syphilitic lesions. Clin Microbiol Rev. 2005;18:205-16.
8. Katz KA. Syphilis. In: Goldsmith LA, Katz SI, Gilchrest BA, Paller AS, Leffell DJ, Wolff K, editors. Fitzpatrick's dermatology in general medicine. $8^{\text {th }}$ ed. New York: McGrawHill; 2012. chapter 200.

9. Adamson HG. Small follicular syphilide of the corymbose type. Proc R Soc Med. 1910;3(Dermatol Sect):1.

10. Kennedy CT, Sanderson KV. Corymbose secondary syphilis: occurrence as a solitary group of lesions. Arch Dermatol. 1980;116:111-2.

11. Christian CW, Lavelle J, Bell LM. Preschoolers with syphilis. Pediatrics. 1999;103:E4.

12. Velasco-Tamariz V, Rodríguez-Peralto JL, Ortiz-Romero P. Corymbiform lesions in a young healthy man. JAMA Dermatol. 2017;153:1317-8.

13. Veasey JV, Salem LA, Santos FH. Corymbiform syphilis associated with three other sexually transmitted infections. An Bras Dermatol. 2018;93:129-32.

14. Fournier A. Traité de la syphilis. Tome I: période primaire période secondaire. Paris: J. Rueff; 1906.

15. Greaves AV. The cutaneous manifestations of syphilis. Can Med Assoc J. 1918;8:417-23.

16. Stokes JH. Modern clinical syphilology: diagnosis, treatment, case studies. $2^{\text {nd }}$ ed. Philadelphia: W. B. Saunders; 1934. 